\title{
Age at referral for diagnosis and rehabilitation services for cerebral palsy: a scoping review
}

\author{
ZACHARY BOYCHUCK ${ }^{1,2,3}$ (D) | ANDRÉ BUSSIÈRES ${ }^{1,2}$ (D) | JESSICA GOLDSCHLEGER ${ }^{1}$ | \\ ANNETTE MAJNEMER ${ }^{1,2,3}$ (D) | THE PROMPT GROUP*
}

1 School of Physical and Occupational Therapy, McGill University, Montreal, OC; 2 Centre for Interdisciplinary Research in Rehabilitation of Greater Montreal (CRIR), Montreal, QC; 3 Research Institute of the McGill University Health Centre, Montreal, OC, Canada.

Correspondence to Annette Majnemer, 3605 de la Montagne, Room 113, H3G 2M1, Montreal, QC, Canada. E-mail: annette.majnemer@mcgill.ca

*See Appendix S1 (online supporting information) for names and affiliations of the members of The PROMPT Group.

\section{PUBLICATION DATA}

Accepted for publication 31 st July 2018

Published online 1st October 2018

\section{ABBREVIATIONS}

NICU Neonatal intensive care unit

PCP Primary care practitioner
AIM This study sought to: (1) determine what is known about age at referral for diagnosis and rehabilitation services for children suspected of having cerebral palsy (CP); and (2) identify factors associated with earlier referral.

METHOD A scoping review was conducted to summarize existing literature. We systematically searched Allied and Complementary Medicine, CINAHL, Cochrane Library, Embase, and PsycINFO for evidence published between 1979 and 2017 on age at referral for diagnosis or age at referral to rehabilitation services for children suspected of having CP. Quantitative and thematic analyses of the literature were performed.

RESULTS Our search yielded 777 articles, of which 15 met the inclusion criteria. Only one study focused on age at referral for diagnosis of CP (mean $16.6 \mathrm{mo} \pm 19.2 \mathrm{mo}$ ), with two on age at referral to rehabilitation services (means $13.9 \mathrm{mo} \pm 15.8 \mathrm{mo}$ and $12.4 \mathrm{mo}$ ). Potential predictors of earlier referral identified include referral source, type of $\mathrm{CP}$, and a complicated birth history.

INTERPRETATION Evidence is sparse; however, available studies suggest high variation in the age at which children are being referred for diagnosis, typically ranging from 10 months to 21 months. Evidence indicates that subgroups of children with $\mathrm{CP}$ might be experiencing prolonged delays. Findings highlight the need to better understand what contributes to delays in referral for diagnosis and rehabilitation.
Cerebral palsy (CP) is the fourth most common childhood disability, ${ }^{1}$ and the most common physical disability encountered in children, ${ }^{2}$ with an estimated prevalence of 2.3 per 1000 live births. ${ }^{3}$ A consensus definition of CP describes it as group of disorders of the development of movement and posture resulting from damage in the fetal or infant brain, often accompanied by secondary sensory impairments. ${ }^{4}$ Current best practice for children suspected of having CP recommends early identification and referral both to medical specialists for diagnosis and to rehabilitation professionals for intervention. ${ }^{5}$ Early identification of developmental disabilities is widely supported by the American and Canadian pediatric professional societies, ${ }^{6,7}$ and is endorsed at a policy level. ${ }^{8,9}$ There is evidence to suggest that delayed referral can limit a child's ability to reach their full potential in developmental skills. ${ }^{10}$ Delayed referral for diagnosis can also be detrimental to the child's family from a psychosocial perspective. Diagnosis in and of itself is a period of crisis analogous to bereavement, ${ }^{11,12}$ and parental dissatisfaction with the disclosure process has been linked to later maternal depression, poor adaptive coping, and increased parental stress. ${ }^{13,14}$ Conversely, parental satisfaction with disclosure (e.g. early diagnosis, positive attributes of the physician, informative content) has been linked with better adaptation. ${ }^{15,16}$ Failure to promptly identify and support parental psychosocial issues may contribute to mental health morbidity for the family of the child with $\mathrm{CP} .{ }^{17}$

According to Canadian and Australian CP registries, approximately $40 \%$ to $45 \%$ of children with CP are born preterm; ${ }^{18,19}$ however, only a subset, typically those no older than 29 weeks, are closely monitored by a neonatal follow-up program, with the children determined not to be at 'high-risk' of CP discharged to care in the community. In addition, many children with $\mathrm{CP}$ are born at term and may not have a high-risk history. Primary care practitioners (PCPs), such as pediatricians and family physicians, are thus uniquely positioned to serve a crucial role in identifying these children and referring them to medical specialists for timely diagnosis, and to rehabilitation professionals for intervention. Importantly, PCPs do not receive the same advanced training in early childhood development as child 
neurologists and developmental pediatricians. Not surprisingly perhaps, wide variability currently exists in their knowledge and practice with respect to identifying children with developmental disabilities. ${ }^{20,21}$

Apart from lacking an awareness of the early motor signs of CP, PCPs and parents may be unaware of the roles rehabilitation professionals have in early intervention. Unnecessary delays in intervention may result from the linear serial model of referral, where diagnosis is often the gateway for referral to rehabilitation services. ${ }^{22,23}$ In summary, although early identification is widely endorsed, about half of children with CP do not benefit from close monitoring and PCPs may not be adequately informed to detect $\mathrm{CP}$ in this population. Thus, there is concern about delays in referral for diagnosis of CP.

The focus of this review is on age at referral rather than age at diagnosis as there may be strategies to optimize earlier detection by PCPs and decrease age at referral. Age at diagnosis may also be influenced by waiting lists, which is a systemic issue. Nevertheless, as part of this scoping review, we also documented age at diagnosis of $\mathrm{CP}$ and age at rehabilitation intervention as they may provide useful information related to potential predictors of earlier or delayed diagnosis. Therefore, the primary aim of this study was to determine from the existing literature what is known about age at referral for diagnosis and for rehabilitation services of children suspected of having CP. A second aim was to identify factors potentially predictive of earlier or delayed referral for diagnosis.

\section{METHOD}

A scoping review was conducted on the basis of the framework proposed by Arksey and O'Malley, ${ }^{24}$ and informed by the enhancements proposed by Levac et al. ${ }^{25}$

\section{Identifying the research question}

The research question guiding this review was the following: what is known from the existing literature about the age at referral for diagnosis of children suspected of having $\mathrm{CP}$, and what factors have been associated with earlier referral?

\section{Identifying relevant studies}

Given we anticipated that there would be a limited literature addressing this research question, we also included literature on age at diagnosis of CP, as well as age at referral to rehabilitation services. With the assistance of an information specialist, an electronic-database search strategy was developed in MEDLINE and adapted for Allied and Complementary Medicine, CINAHL, Cochrane Library, Embase, and PsycINFO to uncover studies reporting on age at referral for diagnosis of CP using a combination of keywords and Medical Subject Headings (MeSH) terms: cerebral palsy, spastic hemiplegia, spastic diplegia, spastic tetraplegia, spastic quadriplegia, dyskinesia, ataxia, age, delay, later, early, referral, consultation, primary healthcare, secondary care, tertiary healthcare, diagnosis, and

\section{What this paper adds}

- Evidence on age at referral for diagnosis of cerebral palsy is sparse.

- Potential predictors of delayed referral represent targets to minimize delays in diagnosis.

- A subset of children may be experiencing unnecessary delays in referral.

detection. Articles were also identified through reference list screening/hand searching.

\section{Study selection}

Studies were limited to original published research and expert opinion that had undergone the rigor of peer review (grey literature, anecdotal, and expert-opinion sources were thus excluded), published in English or French, from 1979 to 2017 inclusively. The clinical population of interest was limited to infants and young people under 18 years of age with CP. Studies were limited to those with a primary focus on age at referral for diagnosis of $\mathrm{CP}$ and age at diagnosis of $\mathrm{CP}$ (e.g. studies focusing on risk factors for CP were excluded).

For this study, age at referral for diagnosis of $\mathrm{CP}$ was operationalized as the age in months at which a child was referred for diagnosis, usually from a PCP to a medical specialist (e.g. child neurologist, developmental pediatrician) for diagnosis of $\mathrm{CP}$. Age at diagnosis of $\mathrm{CP}$ was operationalized as the age in months at which a child formally received a diagnosis of $\mathrm{CP}$, usually from a medical specialist. For this study, ages at 'identification' or 'presentation' were included as age at diagnosis. Age at referral for rehabilitation services and age at rehabilitation intervention were similarly operationalized.

Three reviewers ( $\mathrm{ZB}, \mathrm{JG}$, and $\mathrm{AM})$ were involved in the study screening and selection process. Two levels of screening were performed: (1) title/abstract; and (2) full text. Initially all titles/abstracts were screened for eligibility by $\mathrm{ZB}$ and JG, with $\mathrm{AM}$ available to discuss and resolve potential discrepancies. Before this initial level of screening, a calibration exercise was conducted to ensure reliability in correctly selecting articles for inclusion: $\mathrm{ZB}$ and JG randomly selected $5 \%$ ( $n=30$ out of 597$)$ of the retrieved titles/abstracts, and interrater reliability exercises were performed using a predefined relevance criteria form, which demonstrated very good agreement (Cohen's $k=0.84$ ). The two reviewers then divided and completed the remaining title/abstract screenings independently. The second level of screening involved reading the full text of each article retained from the title/abstract screening. $\mathrm{ZB}$ completed the full-text reviews, and AM was consulted as needed for further clarification of any ambiguities.

\section{Charting the data}

Using a descriptive-analytical method, ${ }^{26}$ the authors applied an iterative approach in the development and integration of the data charting form. The following information was recorded for each study as available: author, year of publication, title, country of publication, research methodology/type of study, clinical population/sample 
characteristics, information on age at referral for diagnosis, information on age at diagnosis, information on age at referral for rehabilitation, and information on age at initiation of rehabilitation services. Differences in extraction were resolved by discussion or with the involvement of a third reviewer (AM) if consensus could not be reached. Studies were excluded at the full-text review level if during data extraction some exclusion criteria were identified.

\section{Collating, summarizing, and reporting the results}

In accordance with Arksey and O'Malley, ${ }^{24}$ no formal quality assessment of the included studies was made as the aim of this scoping review was to identify the breadth of the literature and the major areas of research activity with corresponding resulting themes. As suggested by Levac et al., ${ }^{25}$ we incorporated both a quantitative analysis (numerical summary) and qualitative analysis (identification of factors related to earlier or delayed referral). Also true to the scoping review methodology, the analytical description of studies is meant to identify directions for practice and gaps that should be addressed in future research.

\section{RESULTS}

\section{Descriptive numerical analysis}

As outlined in Figure S1 (online supporting information), a total of 777 articles were initially retrieved through the database searches, cross-referencing, and hand searching, with 15 eventually retained for the final analysis. Most studies were descriptive cohort studies with no testing of factors related to predictive factors of age at referral, and no specific recommendations for practice (Table I).

\section{Age at referral for $\mathrm{CP}$ diagnosis}

Only one study reported on age at referral for diagnosis. A retrospective chart review $^{27}$ found that children were referred for diagnosis at a mean age of 16.6 months, with high variability. Fifty-eight percent of children were referred before 1 year of age, $23 \%$ between 1 year and 2 years of age, $6 \%$ between 2 years and 3 years of age, and $13 \%$ were 3 years of age or older.

\section{Age at $\mathrm{CP}$ diagnosis}

Eight studies reported on age at diagnosis, ${ }^{5,28-34}$ which ranged between 8 months and 24 months. Several other authors ${ }^{23,35-37}$ suggested that $\mathrm{CP}$ can be diagnosed as early as 12 weeks, but may be more reliable as late as 36 months.

\section{Age at referral to rehabilitation services}

Only two studies reported on age at referral for rehabilitation services. ${ }^{27,38}$ The mean age ranged between 12 months and 14 months, again with wide variability.

\section{Age at initial rehabilitation intervention}

Only one study focused on age at rehabilitation intervention. Colver ${ }^{39}$ reported on the age at initiation of rehabilitation services for two cohorts of children with three types of CP. Children with quadriplegia received services earlier than the other subtypes. Age at intervention was earlier for children in the later birth cohort.

\section{Qualitative analysis}

Analysis of the included studies $(n=10)$ revealed several potential predictors of earlier referral (Table SI, online supporting information).

\section{Factors influencing age at referral for diagnosis}

Three potential predictors of referral at a younger age for diagnosis were identified in one study. ${ }^{27}$ First, referral source (operationally defined by the authors as a medical specialist [e.g. child neurologist] or PCP [e.g. pediatrician]) was identified. Medical specialists accounted for most of the referrals and flagged children for diagnosis significantly earlier than PCPs. Second, having had a complicated birth history (an initial admission to a neonatal intensive care unit [NICU]) was identified. Children initially admitted to a NICU were referred for diagnosis significantly earlier than children not initially admitted to a NICU. Third, type of CP (diplegia, hemiplegia, quadriplegia, mixed, 'other') was identified. Children with certain subtypes of CP (diplegia, hemiplegia) are experiencing significant delays.

\section{Factors influencing age at diagnosis}

Two potential predictors of a younger age at diagnosis were identified. Comparing type of $\mathrm{CP}$, Lock et al. ${ }^{31}$ found the mean ages of presentation for children with quadriplegia were earlier than for children with diplegia. Of note, the authors concluded that $\mathrm{CP}$ subtype is an insignificant predictor of earlier diagnosis, although it is important to note that their sample size $(n=57)$ was small and did not include any children with hemiplegia.

The second potential predictor of a younger age at diagnosis was severity of motor impairment. One study ${ }^{30}$ reported a median age at diagnosis of 11.1 months across CP types, although $6.6 \%$ were diagnosed at age 5 years or older, with an earlier diagnosis associated with a higher degree of motor disability. The Australian CP Registry indicated that the average age for a description of CP is 19 months, but the authors noted the wide variability in clinical practice with description as early as 1 week old for children with more severe impairment, to 5 years of age for children with mild to moderate severity. ${ }^{5}$

\section{Factors influencing age at referral to rehabilitation services}

Three potential predictors of referral at a younger age for rehabilitation services were identified. Hubermann et al. ${ }^{27}$ suggested that a complicated birth history may be a factor. The subset of children initially hospitalized in the NICU was referred for treatment earlier than children who were discharged home and did not receive neonatal follow-up. Lindstrom and Bremberg ${ }^{38}$ offered two potential predictors. The first was referral source, since most of the children referred at younger ages came from medical specialists with advanced clinical training in early infant 
Table I: A summary of the characteristics of the included studies $(n=15)$

\begin{tabular}{|c|c|c|c|c|}
\hline References & Country & $\begin{array}{l}\text { Study design/ } \\
\text { research } \\
\text { methodology }\end{array}$ & Clinical population/sample characteristics & $\begin{array}{l}\text { Information on age at referral for diagno- } \\
\text { sis; age at diagnosis; age at rehabilitation }\end{array}$ \\
\hline $\begin{array}{l}\text { Ashwal } \\
\text { et al. }{ }^{35}\end{array}$ & USA & $\begin{array}{l}\text { Practice } \\
\text { parameter: } \\
\text { literature } \\
\text { review }\end{array}$ & All included studies had $\geq 20$ patients & The diagnosis of $\mathrm{CP}$ is given before age $2 \mathrm{y}$ \\
\hline Bennett ${ }^{28}$ & USA & Commentary & & Average age at diagnosis of $\mathrm{CP}$ was $18 \mathrm{mo}$ \\
\hline $\begin{array}{l}\text { Bosanquet } \\
\text { et al. }\end{array}$ & Australia & $\begin{array}{l}\text { Systematic } \\
\text { review }\end{array}$ & $\begin{array}{l}\text { All included studies ( } n=19 \text { ) assessed children at } \\
\text { high-risk of CP only }\end{array}$ & $\begin{array}{l}\text { Propose CP can be more reliably assessed } \\
\text { and diagnosed at } 36 \mathrm{mo}\end{array}$ \\
\hline $\begin{array}{l}\text { Byrne } \\
\text { et al. }\end{array}$ & USA & $\begin{array}{l}\text { Prospective } \\
\text { cohort study }\end{array}$ & $\begin{array}{l}\text { Infants at high-risk of CP: } \\
\text { cohort A: 2014-2015 ( } n=70) \\
\text { cohort B: 2016-2017 }(n=175)\end{array}$ & $\begin{array}{l}\text { Mean age at diagnosis: } \\
\text { cohort A: } 18 \mathrm{mo} \pm 7 \mathrm{mo} \text {, range } 11 \mathrm{mo}-32 \mathrm{mo} \\
\text { cohort B: } 13 \mathrm{mo} \pm 4 \mathrm{mo} \text {, range } 4 \mathrm{mo}-29 \mathrm{mo}\end{array}$ \\
\hline Colver ${ }^{39}$ & UK & $\begin{array}{l}\text { Descriptive } \\
\text { cohort study }\end{array}$ & $\begin{array}{l}\text { All children of preschool age in Northumberland } \\
\text { ( } 3600 \text { births each year) }\end{array}$ & $\begin{array}{l}\text { Average age at which physiotherapy began } \\
\text { for children with CP: } \\
\text { birth years } 1970-1977 \\
\text { quadriplegia }(6.5 \mathrm{mo}) \\
\text { diplegia }(23 \mathrm{mo}) \\
\text { hemiplegia }(21 \mathrm{mo}) \\
\text { birth years } 1978-1985 \\
\text { quadriplegia }(6.5 \mathrm{mo}) \\
\text { diplegia (10mo) } \\
\text { hemiplegia }(12 \mathrm{mo})\end{array}$ \\
\hline $\begin{array}{l}\text { Granild- } \\
\text { Jensen } \\
\text { et al. }{ }^{30}\end{array}$ & Denmark & $\begin{array}{l}\text { Descriptive } \\
\text { retrospective } \\
\text { cohort study }\end{array}$ & $\begin{array}{l}1291 \text { children with CP born 1995-2003; registry, } \\
\text { population-based }\end{array}$ & $\begin{array}{l}\text { Median age at diagnosis reported was } \\
11.1 \mathrm{mo} \text { across CP types; } 6.6 \% \text { were } \\
\text { diagnosed at age } 5 y \text { or older }\end{array}$ \\
\hline $\begin{array}{l}\text { Hubermann } \\
\text { et al. }{ }^{27}\end{array}$ & Canada & $\begin{array}{l}\text { Retrospective } \\
\text { chart review }\end{array}$ & 103 children with $\mathrm{CP}$, born $2002-2012$ & $\begin{array}{l}\text { Mean age at referral for diagnosis }(n=99) \\
\text { was } 16.6 \mathrm{mo} \pm 19.2 \mathrm{mo} \text { (range } 0.1 \mathrm{mo}- \\
89.9 \mathrm{mo} \text { ) } \\
\text { Mean age at referral to rehabilitation } \\
\text { services }(n=90) \text { was } 13.9 \mathrm{mo} \pm 15.8 \mathrm{mo} \\
\text { (range } 0.1 \mathrm{mo}-79.5 \mathrm{mo})\end{array}$ \\
\hline $\begin{array}{l}\text { Lindstrom } \\
\text { and } \\
\text { Bremberg } \\
\end{array}$ & Sweden & $\begin{array}{l}\text { Retrospective } \\
\text { cohort study }\end{array}$ & 23924 children born $1986-1990$ ( $n=66$ with CP) & $\begin{array}{l}\text { Mean age of referral to a habilitation unit } \\
\text { was } 12.4 \mathrm{mo} \text { (range } 0.5 \mathrm{mo}-54 \mathrm{mo} \text { ) }\end{array}$ \\
\hline Lock et al. ${ }^{31}$ & USA & $\begin{array}{l}\text { Retrospective } \\
\text { chart review }\end{array}$ & $\begin{array}{l}738 \text { consecutive children referred for } \\
\text { developmental evaluation between } 1982 \text { and } \\
1983(n=57 \text { with CP) }\end{array}$ & $\begin{array}{l}\text { Mean age of presentation: } \\
\text { diplegia: } 15.9 \mathrm{mo} \\
\text { quadriplegia: } 12.1 \mathrm{mo}\end{array}$ \\
\hline $\begin{array}{l}\text { Mclntyre } \\
\text { et al. }{ }^{5}\end{array}$ & Australia & Review & $\mathrm{N} / \mathrm{A}$ & $\begin{array}{l}\text { Average age for a description of } \mathrm{CP} \text { to be } \\
\text { given is } 19 \mathrm{mo}\end{array}$ \\
\hline Novak $^{23}$ & Australia & Review & $N / A$ & $\begin{array}{l}\mathrm{CP} \text { is historically diagnosed around } 12 \mathrm{mo}- \\
24 \mathrm{mo} \\
\text { Diagnosis at } 12 \text { wks possible for children at } \\
\text { high-risk; early diagnosis for 'healthy term } \\
\text { borns' requires further research }\end{array}$ \\
\hline $\begin{array}{l}\text { Novak } \\
\text { et al. }{ }^{37}\end{array}$ & Australia & $\begin{array}{l}\text { Systematic } \\
\text { review }\end{array}$ & Children at high-risk for $\mathrm{CP}$ & $\begin{array}{l}\text { Diagnosis is usually made between } 12 \mathrm{mo} \\
\text { and } 24 \mathrm{mo} \text {, but now possible before } 6 \mathrm{mo} \\
\text { corrected age }\end{array}$ \\
\hline $\begin{array}{l}\text { Palfrey } \\
\text { et al. }^{32}\end{array}$ & USA & $\begin{array}{l}\text { Cross- } \\
\text { sectional } \\
\text { survey }\end{array}$ & $\begin{array}{l}\text { All children in special education programs in five } \\
\text { census districts ( } n=1726 \text { children) }\end{array}$ & $\begin{array}{l}\text { Mean age of identification of CP was } \\
10.3 \mathrm{mo}\end{array}$ \\
\hline Stanley ${ }^{33}$ & Australia & $\begin{array}{l}\text { Retrospective } \\
\text { cohort study }\end{array}$ & $\begin{array}{l}\text { All children with the diagnosis of CP born in } \\
\text { Western Australia between January } 1 \text { st, } 1956 \text { and } \\
\text { December } 31 \text { st, } 1975 \text { ( } n=917 \text { children with CP) }\end{array}$ & $\begin{array}{l}\text { Mean age at diagnosis was } 21 \mathrm{mo} \text {; median } \\
\text { age } 11 \mathrm{mo} ; 3 \% \text { of children diagnosed later } \\
\text { than } 36 \mathrm{mo}\end{array}$ \\
\hline $\begin{array}{l}\text { Tirosh } \\
\text { et al. }^{34}\end{array}$ & Israel & $\begin{array}{l}\text { Population- } \\
\text { based survey }\end{array}$ & $\begin{array}{l}\text { All children part of developmental screening from } \\
\text { January } 1979 \text { to December 1984; } 29108 \text { children } \\
\text { ( } n=66 \text { children with CP) }\end{array}$ & $\begin{array}{l}\text { At diagnosis of CP: } \\
42.5 \% \text { were } 1 \mathrm{mo}-12 \mathrm{mo} \\
43.9 \% \text { were } 13 \mathrm{mo}-24 \mathrm{mo} \\
13.6 \% \text { were } 25 \mathrm{mo}-36 \mathrm{mo}\end{array}$ \\
\hline
\end{tabular}

$\mathrm{CP}$, cerebral palsy.

motor development. The second was severity of motor impairment, as the authors found that children with a 'mild' CP were referred much later than children with 'moderate' or 'severe' CP.

\section{Factors influencing age at rehabilitation intervention}

Type of CP was identified as a potential predictor of initiating rehabilitation services at younger age. Colver ${ }^{39}$ reported that children with quadriplegia received the earliest intervention compared with children with other subtypes of CP.

\section{DISCUSSION}

To our knowledge, this is the first review of the literature on age at referral for diagnosis for children suspected of having CP. We performed a comprehensive search of 
electronic databases, and had very good interrater reliability during the screening and abstraction phases.

The results of this scoping review demonstrate that available evidence is sparse about the current referral practices of PCPs for children with $\mathrm{CP}$, especially with respect to the age at which children are currently being referred to medical specialists for diagnosis of CP. Most of the few available studies are older and report on birth cohorts from the mid-1950s to the 1980s, but they suggest variations in age at diagnosis ranging from 10 months to 21 months. ${ }^{31-33}$ It is important to note that much of the literature found through this review, and used in clinical practice, is 'expert opinion' in nature. Current evidence lacks population-based data and strong methodological designs to support best-practices. In the single recent study that objectively explored age at referral for diagnosis, there was a high variability in the age at which children were referred (mean $16.6 \mathrm{mo} \pm 19.2 \mathrm{mo}$; range $0.1 \mathrm{mo}-89.9 \mathrm{mo}) .{ }^{27} \mathrm{It}$ is also important to note that most of the research so far in early identification and early intervention has focused on children considered to be at 'high-risk' of CP, potentially biasing the estimated age at referral to an earlier age. ${ }^{5,23}$ Consequently, little is known and further research efforts are required for the almost half of children with CP born at term from uncomplicated pregnancies, or who are born preterm (i.e. 30-36wks gestational age) and subsequently may not have been in a neonatal follow-up program. In the two studies that reported age at referral to rehabilitation services, there was a similar high variability. Hubermann et al. ${ }^{27}$ found wide variability in clinical practice, with some children experiencing delayed referral for diagnosis beyond 3 years of age. Similarly, Lindstrom and Bremberg ${ }^{38}$ reported that some children experienced delays for referral as late as age 4 years 6 months.

Some factors have been identified as being potentially predictive of a younger age at referral both for diagnosis and for rehabilitation services. The first is referral source, with PCPs seeming to refer for diagnosis later than medical specialists. Since they often do not have the advanced training that medical specialists receive in early infant motor development, it is possible that PCPs may not recognize signs of early motor delay in their clinical practice for the subset of children who are discharged home without neonatal follow-up. It is important to acknowledge that medical specialists may be evaluating children with more severe impairment, or more high-risk infants through neonatal follow-up programs, which may in part explain the finding of earlier detection. The second potential predictor is having had a complicated birth bistory. The prenatal, perinatal, and postnatal risk factors for CP are well known, with some of the most important ones being low birthweight, known intrauterine infections, and multiple gestation. ${ }^{40}$ Since these early risk factors are often associated with prompt neonatal follow-up that includes close developmental surveillance, children who fit this profile are more likely to be identified and referred earlier than those who are discharged home without neonatal follow-up. Not surprisingly, severity of motor impairment may be a third potential predictor of a younger age at referral, with children having more severe motor impairment being identified and referred earlier.

Synthesizing these results, it is possible that there are two catchments of children with CP: (1) children with a complicated birth history (initial NICU admission), who are referred early for diagnosis and rehabilitation services by medical specialists from neonatal follow-up programs; and (2) children who do not have a complicated birth history (no risk factors, no initial NICU admission), or are NICU graduates who do not meet criteria for entry to a neonatal follow-up program, and are discharged to the community and probably lost to follow-up until later age when other delays may present.

While early identification and early intervention are widely accepted as best practice for children suspected of having $\mathrm{CP}$, the available evidence suggests that an important knowledge-to-practice gap may exist. If PCPs lack the knowledge of the early signs of $\mathrm{CP}$, they will continue to experience challenges in detection in their practice, and children will continue to experience delayed referral for diagnosis and rehabilitation. Our findings have important implications for stakeholders, researchers, and decisionmakers. Physicians (especially PCPs) and parents need to be better informed on the early motor signs of CP. Continuing monitoring and support to address potential concerns related to a child's motor development area are also needed.

This review, however, is not without limitations. We did not search the grey literature, and restricted the search to English and French publications published as of 1979, excluding abstracts and conference proceedings. These decisions possibly excluded some relevant studies. Also, as per scoping review methodology, the quality of the included studies was not assessed; thus there is a potential risk of bias inherent from the studies' low-quality methodological design. However, the purpose of this review was not to indicate what would be the best practice in the field, but rather to gather a scope of the existing evidence and current practices. Also, the lack of recent studies across different countries prevented us from making any meaningful comparisons across health care systems.

In a recently published strategic plan for $\mathrm{CP}$ research, the National Institute of Child Health and Human Development and the National Institute of Neurological Disorders and Stroke stress the importance of early intervention, linking successful outcomes with earlier diagnosis and intervention. ${ }^{41}$ The potential benefits of earlier intervention continue to be supported in the literature. As an example, a recently published exploratory study found that the use of baby-constraint induced movement therapy with infants as young as 3 months to 8 months may improve functional outcomes for children with unilateral CP. ${ }^{42}$ To effectively target this recommendation it is essential to better understand the current clinical picture for referral 
practices. This study highlights the need for populationbased data and high methodological designs on the current referral practices of PCPs and the factors that contribute to delays in referral and diagnosis. This would inform the development of evidenced-based knowledge translation tools to enhance early detection and prompt subsequent simultaneous referral for diagnosis, medical management, and rehabilitation services.

\section{CONCLUSION}

Literature is sparse on the current referral practices of PCPs related to children suspected of having CP. Although efforts have been made to promote developmental surveillance, PCPs may lack awareness of the early motor signs of $\mathrm{CP}$, thus unnecessarily prolonging the delays currently experienced in diagnosis and intervention. This study highlights the need for populationbased data on the current referral practices of PCPs and factors associated with delays in referral and diagnosis. This will enable the identification of the precise knowledge gaps that exist in terms of early recognition of $\mathrm{CP}$, which will inform the targeted development of knowledge translation tools to enhance early identification and early intervention. Subsequently, continuing professional development initiatives addressed to PCPs should also be put in place to improve early detection and referral.

\section{ACKNOWLEDGMENTS}

The authors disclose receipt of the following financial support for the research, authorship, and publication of this article: ZB received salary support as a doctoral trainee from the Canadian Institutes of Health Research (MOP-133402), which supported this study in part. ZB also received a financial support from the Richard and Edith Strauss Canada Foundation as a musculoskeletal doctoral fellow, as well as from the Hoppenheim Fund/Montreal Children Hospital Foundation. We thank Pamela Harrison and Jill Boruff for their assistance with the database searches. We also express our gratitude to Deniz Keskinel, Sossy Sahakian, and Annahita Ehsan for their support with the database searches and in preparing the manuscript. No ethical review was required for this study. The authors have stated that they had no interests which might be perceived as posing a conflict or bias.

\section{SUPPORTING INFORMATION}

The following additional material may be found online:

Appendix S1: Members of the PROMPT Group.

Figure S1: Flow chart of study selection.

Table SI: Summary of the studies including information on factors potentially associated with a younger age at referral

\section{REFERENCES}

1. Statistics Canada. Participation and activity limitation survey 2006: analytical report 2006. Statistics Canada Catalogue, 2007. Available from: http://www.statcan. gc.ca/pub/89-628-x/89-628-x2007002-eng.pdf (accessed 11 October 2017).

2. Hirtz D, Thurman DJ, Gwinn-Hardy K, Mohamed M, Chaudhuri AR, Zalutsky R. How common are the "common" neurologic disorders? Neurology 2007; 68: 326-37.

3. Oskoui M, Joseph L, Dagenais L, Shevell M. Prevalence of cerebral palsy in Quebec: alternative approaches. Neuroepidemiology 2013; 40: 264-8.

4. Rosenbaum P, Paneth N, Leviton A, et al. A report: the definition and classification of cerebral palsy April 2006. Dev Med Child Neurol 2007; 49(Suppl. 109): 8-14.

5. McIntyre S, Morgan C, Walker K, Novak I. Cerebral palsy —don't delay. Dev Disabil Res Rev 2011; 17: 114-29.

6. Council on Children with Disabilities; Section on developmental Behavioral Pediatrics; Bright Futures Steering Committee; Medical Home Initiatives for Children with Special Needs Project Advisory Committee. Identifying infants and young children with developmental disorders in the medical home: an algorithm for developmental surveillance and screening. Pediatrics 2006; 118: 405-20.

7. Williams R, Clinton J; Canadian Paediatric Society, Early Years Task Force. Getting it right at 18 months: in support of an enhanced well-baby visit. Position Statement. Paediatr Child Health 2011; 16: 647-50.

8. Government of Manitoba. A young child's assessment and diagnosis. Available from: https://www.gov.mb.ca/ fs/imd/young_child_assess.html (accessed 12 January 2017).

9. Dua V. Standards and guidelines for the assessment and diagnosis of young children with autism spectrum disorder in British Columbia: an evidence-based report prepared for the British Columbia Ministry of Health Planning. 2003. Available from: http://www.phsa.ca/ Documents/asd_standards_0318.pdf (accessed 12 January 2017).

10. Shepherd R. The changing face of intervention in infants with cerebral palsy. In: Shepherd R, editor. Cerebral Palsy in Infancy: Targeted Activity to Optimize Early Growth and Development. Edinburgh: Elsevier Health Sciences, 2013: 3-28.

11. Huang Y, Kellett U, St John W. Cerebral palsy: experiences of mothers after learning their child's diagnosis. 7 Adv Nurs 2010; 66: 1213-21.

12. Schuengel C, Rentinck IC, Stolk J, et al. Parents' reactions to the diagnosis of cerebral palsy: associations between resolution, age and severity of disability. Child Care Health Dev 2009; 35: 673-80.

13. Baird G, McConachie H, Scrutton D. Parents' perceptions of disclosure of the diagnosis of cerebral palsy. Arch Dis Child 2000; 83: 475-80.

14. Dagenais L, Hall N, Majnemer A, et al. Communicating a diagnosis of cerebral palsy: caregiver satisfaction and stress. Pediatr Neurol 2006; 35: 408-14.

15. Rentinck IC, Ketelaar M, Jongmans MJ, Gorter J. Parents of children with cerebral palsy: a review of factors related to the process of adaptation. Child Care Health Dev 2007; 33: 161-9.
16. Shevell AH, Shevell M. Doing the 'talk': disclosure of a diagnosis of cerebral palsy. 7 Child Neurol 2013; 28 : $230-5$.

17. Bemister TB, Brooks BL, Dyck RH, Kirton A. Predictors of caregiver depression and family functioning after perinatal stroke. BMC Pediatr 2015; 15: 75.

18. Australian Cerebral Palsy Register. Report of the Australian Cerebral Palsy Register, Birth Years 1993-2006. Sydney: Cerebral Palsy Alliance Research Institute, 2013.

19. Shevell M, Dagenais L, Oskoui M. The epidemiology of cerebral palsy: new perspectives from a Canadian registry. Semin Pediatr Neurol 2013; 20: 60-4.

20. Liptak GS, Orlando M, Yingling JT, et al. Satisfaction with primary health care received by families of children with developmental disabilities. 7 Pediatr Health Care 2006; 20: 245-52.

21. Sices L, Feudtner C, McLaughlin J, Drotar D, Williams M. How do primary care physicians identify young children with developmental delays? A national survey. $f$ Dev Behav Pediatr 2003; 24: 409-17.

22. Noritz GH, Murphy NA; Neuromotor Screening Expert Panel. Motor delays: early identification and evaluation. Pediatrics 2013; 131: e2016-27.

23. Novak I. Evidence-based diagnosis, health care, and rehabilitation for children with cerebral palsy. 7 Cbild Neurol 2014; 29: 1141-56.

24. Arksey H, O'Malley L. Scoping studies: towards a methodological framework. Int 7 Soc Res Methodol 2005; 8: 19-32.

25. Levac D, Colquhoun H, O'Brien KK. Scoping studies: advancing the methodology. Implement Sci 2010; 5: 69. 
26. Pawson R. Evidence-based policy: in search of a method. Evaluation 2002; 8: 157-81.

27. Hubermann L, Boychuck Z, Shevell M, Majnemer A. Age at referral of children for initial diagnosis of cerebral palsy and rehabilitation current practices. 7 Child Neurol 2016; 31: 364-9.

28. Bennett FC. Diagnosing cerebral palsy - the earlier the better. Contemp Pediatr 1999; 16: 65-76.

29. Byrne R, Noritz G, Maitre NL; NCH Early Developmental Group. Implementation of early diagnosis and intervention guidelines for cerebral palsy in a high-risk infant follow-up clinic. Pediatr Neurol 2017; 76: 66-71.

30. Granild-Jensen JB, Rackauskaite G, Flachs EM, Uldall P. Predictors for early diagnosis of cerebral palsy from national registry data. Dev Med Child Neurol 2015; 57: 931-5.

31. Lock TM, Shapiro BK, Ross A, Capute AJ. Age of presentation in developmental disability. 7 Dev Behav Pediatr 1986; 7: 340-5.

32. Palfrey JS, Singer JD, Walker DK, Butler JA. Early identification of children's special needs: a study in five metropolitan communities. 7 Pediatr 1987; 111: 651-9.
33. Stanley FJ. An epidemiological study of cerebral palsy in Western Australia, 1956-1975. I: changes in total incidence of cerebral palsy and associated factors. Dev Med Child Neurol 1979; 21: 701-13.

34. Tirosh E, Shapira M, Jaffe M, Tamir A, Zelnik N. Developmental disabilities among children between birth and 3 years old in the Haifa district: a population study. 7 Dev Behav Pediatr 1993; 14: 323-7.

35. Ashwal S, Russman BS, Blasco PA, et al. Practice parameter: diagnostic assessment of the child with cerebral palsy. Report of the Quality Standards Subcommittee of the American Academy of Neurology and the Practice Committee of the Child Neurology Society. Neurology 2004; 62: 851-63.

36. Bosanquet M, Copeland L, Ware R, Boyd R. A systematic review of tests to predict cerebral palsy in young children. Dev Med Child Neurol 2013; 55: 418-26.

37. Novak I, Morgan C, Adde L, et al. Early, accurate diagnosis and early intervention in cerebral palsy: advances in diagnosis and treatment. 7AMA Pediatr 2017; 171: 897-907.
38. Lindstrom K, Bremberg S. The contribution of developmental surveillance to early detection of cerebral palsy. Acta Paediatr 1997; 86: 736-9.

39. Colver AF. Health surveillance of preschool children: four years' experience. BMF 1990; 300: 1246-8.

40. Odding E, Roebroeck ME, Stam HJ. The epidemiology of cerebral palsy: incidence, impairments and risk factors. Disabil Rehabil 2006; 28: 183-91.

41. National Institute of Neurological Disorders and Stroke (NINDS), Eunice Kennedy Shriver National Institute of Child Health and Human Development (NICHD). Strategic plan for cerebral palsy research. 2017. Available from: https://www.ninds.nih.gov/sites/default/files/ NINDS_NICHD_2017_StrategicPlanCerebralPalsyRe search_508C.pdf (accessed 7 October 2017).

42. Eliasson AC, Nordstrand L, Ek L, et al. The effectiveness of baby-CIMT in infants younger than 12 months with clinical signs of unilateral-cerebral palsy; an explorative study with randomized design. Res Dev Disabil 2018; 72: 191-201.

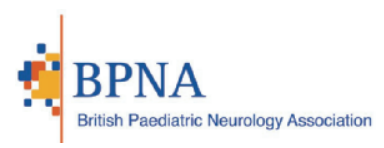

Paediatric Epilepsy Training

\section{Complete PET1, 2 \& 3 courses delivered over one week Cambridge, England \\ 28 October-1 November 2019 \\ 2019 updated materials are now available}

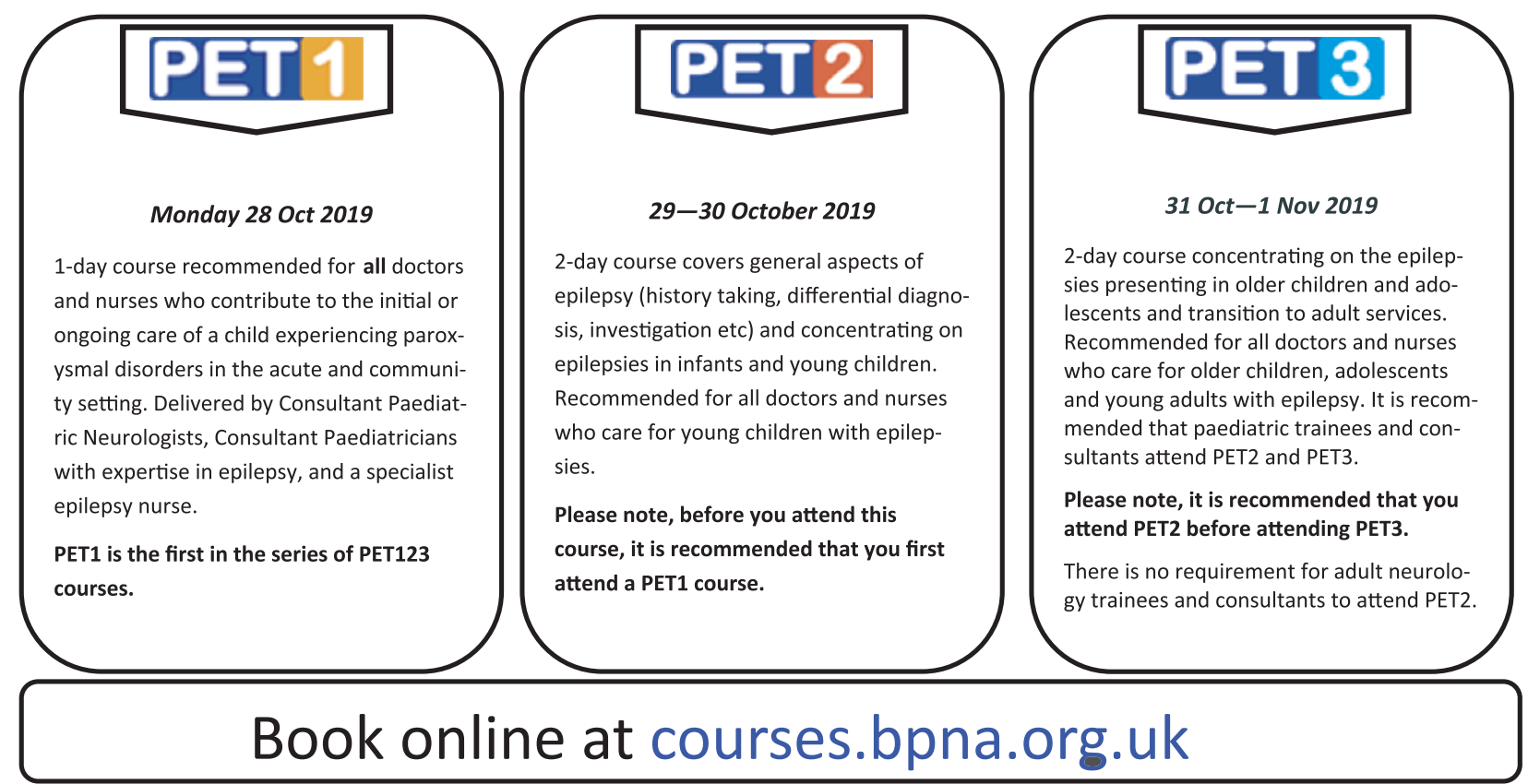




\section{RESUMEN}

EDAD DE DERIVACIÓN A LOS SERVICIOS DE DIAGNÓSTICO Y REHABILITACIÓN EN LA PARÁLISIS CEREBRAL: REVISIÓN DEL ALCANCE

OBJETIVO Este estudio buscó (1) determinar qué se conoce sobre la edad de derivación a los servicios de diagnóstico y rehabilitación de niños con sospecha de tener parálisis cerebral (PC) e (2) identificar factores asociados con una derivación más temprana.

MÉTODO Se llevó a cabo una revisión panorámica para resumir la literatura existente. Buscamos sistemáticamente en Allied and Complementary Medicine, CINAHL, Cochrane Library, Embase, and PsyclNFO la evidencia publicada entre 1979 y 2017 sobre la edad de derivación para el diagnóstico o la edad de derivación a los servicios de rehabilitación de niños con sospecha de PC. Se realizaron análisis cuantitativos y temáticos de la literatura.

RESULTADOS Nuestra búsqueda arrojó 777 artículos, de los cuales 15 cumplieron los criterios de inclusión. Solo un estudio estaba enfocado en la edad de la derivación para el diagnóstico de PC (media $16.6 \mathrm{~m} \pm 19.2 \mathrm{~m}$ ), y dos sobre la edad de derivación a los servicios de rehabilitación (media $13.9 \mathrm{~m} \pm 15.8 \mathrm{~m}$ and $12.4 \mathrm{~m}$ ). Los posibles predictores de la derivación más temprana incluyen la procedencia de la derivación, el tipo de PC, y una historia de nacimiento con complicaciones.

INTERPRETACIÓN La evidencia es escasa; sin embargo, los estudios disponibles sugieren que existe una alta variación de la edad en la que los niños son derivados para ser diagnosticados, típicamente oscilando entre los 10 meses y los 21 meses. La evidencia indica que subgrupos de niños con PC pueden estar experimentando retrasos prolongados. Los hallazgos resaltan la necesidad de comprender mejor lo que contribuye al retraso en la derivación para el diagnóstico y para la rehabilitación.

\section{RESUMO}

\section{IDADE DE ENCAMINHAMENTO PARA DIAGNÓSTICO E SERVIÇOS DE REABILITAÇÃO PARA PARALISIA CEREBRAL: UMA REVISÃO ABRANGENTE}

OBJETIVO Este estudo buscou (1) determinar o que se sabe sobre a idade de encaminhamento para diagnóstico e serviços de reabilitação para crianças com suspeita de paralisia cerebral (PC) e 2) identificar fatores associados com o encaminhamento precoce.

MÉTODO Uma revisão de escopo foi realizada para sintetizar a literatura existente. Nós sistematicamente buscamos a Allied and Complementary Medicine, CINAHL, Biblioteca Cochrane, Embase e PsycINFO por evidências publicadas entre 1979 e 2017 sobre idade no momento do encaminhmento para diagnóstico ou idade no momento do encaminhamento para serviços de reabilitação para crianças com suspeita de PC. Análise quantitativa e temática da literatura foram realizadas.

RESULTADOS Nossa busca resultou em 777 artigos, dos quais 15 atenderam aos critérios de inclusão. Apenas um estudo enfocou a idade de encaminhamento para diagnóstico de PC (média 16,6 $\mathrm{m} \pm 19,2 \mathrm{~m}$ ), com dois sobre a idade de encaminhamento para serviços de reabilitação (média 13,9 $\mathrm{m} \pm 15,8 \mathrm{~m}$ e 12,4 m). Potenciais preditores do encaminhamento precoce incluíram a fonte do encaminhamento, o tipo de PC, e uma história de nascimento complicado.

INTERPRETAÇÃO A evidência é escassa; no entanto, os estudos disponíveis sugerem alta variação na idade em que crianças são encaminhadas para diagnóstico, tipicamente variando de 10 a 21 meses. A evidência indica que subgrupos de crianças com PC podem vivencar atrasos prolongados. Os achados enfatizam a necessidade de compreender melhor o que contribui para os atrasos no encaminhamento para diagnóstico e reabilitação. 